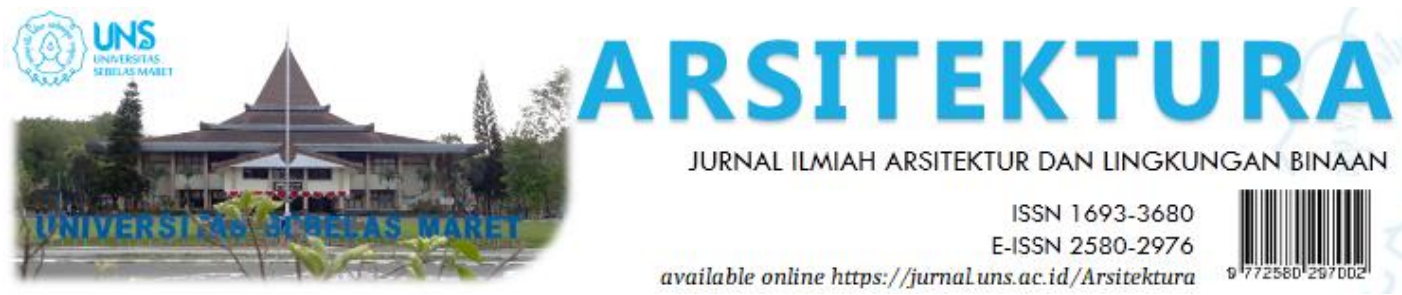

Volume 18 Issue 1 April 2020, pages:119-128

\title{
Identifikasi Pabrik Gula Sebagai Industrial Heritage Di Jawa
}

\section{Sugar Factory Identification as Industrial Heritage in Java}

\author{
Purwanto Setyo Nugroho $^{1 *}$, Nany Yuliastuti ${ }^{2}$, R Siti Rukayah ${ }^{3}$, Rachmadi Nugroho $^{4}$, Untung \\ Joko Cahyono ${ }^{5}$ \\ Progran Studi Arsitektur, Fakultas Teknik Universitas Sebelas Maret ${ }^{{ }^{*}}$ \\ Email: purwantosetyonugroho@staff.uns.ac.id \\ Program Doktor Ilmu Arsitektur dan Perkotaan, Fakultas Teknik, Universitas DiponegoroP ${ }^{2}$ \\ Program Doktor Ilmu Arsitektur dan Perkotaan, Fakultas Teknik, Universitas DiponegoroP ${ }^{3}$ \\ Progran Studi Arsitektur, Fakultas T eknik Universitas Sebelas Maret ${ }^{4}$ \\ Progran Studi Arsitektur, Fakultas T eknik Universitas Sebelas Maret ${ }^{5}$
}

DOI: https://doi.org/10.20961/arst.v18i1.37936

Received: December 13, 2019 Revised : April 27,2020 Accepted: April 27,2020 Available online: April 30,2020

\begin{abstract}
Sugar Factory is a historical marker of the entry of modern industrialization in Java, the existence of a sugar factory is also a witness to the triumph of the sugar industry in Java which was once the second largest sugar supplier in the world. Sugar mills have certain architectural forms and functions, and are recognized as important architectural heritage. This study aims to identify the existence of sugar factories that once existed in Java, and look for aspects related to the importance of sugar factories as industrial heritage with qualitative descriptive methods. Research findings are expected to be useful for conservation preservation activities. The identification results show there are about 231 sugar factories that have ever existed in Java. At present, only 45 factories are still active. Most active sugar mills are located in East Java. Identification that can lead to the determination of the importance of sugar factories as industrial heritage can be seen from the aspects of location, age, function, ownership, physical condition, architectural style and historical events associated with it.
\end{abstract}

Keywords: sugar factory, industrial heritage, Java

\section{PENDAHULUAN}

Praktik heritage dapat dipahami sebagai kegiatan menjaga, mempertahankan, memelihara dan merevitalisasi (preservasi konservasi) obyek heritage dalam dimensi yang luas mencakup artefak, bangunan, kawasan, lanskap kultural dan lanskap natural (Lagerqvist, B. 2011). Kegiatan dalam praktik heritage memerlukan strategi dan metode konservasi yang fleksibel (Logunov, 2003).
Praktik heritage dengan kegiatan preservasi konservasi menjadi bagian dari kegiatan yang lebih luas terkait ketahanan sosial, ekonomi dan ketahanan lingkungan yang pada akhirnya berujung pada proses sosial budaya dalam membentuk peradaban.

Tindakan untuk mengawali praktik heritage adalah dengan mengidentifikasi nilai penting obyek heritage. Identifikasi nilai penting sebuah obyek heritage perlu dilakukan dari 
perspektif multidisiplin dan multi-aktor agar diperoleh visi yang lebih komprehensif dan keterlibatan yang lebih besar dari semua stake holder. Keterlibatan pemangku kepentingan dalam pengelolaan pelestarian warisan telah banyak dibahas di forum internasional dalam beberapa dekade terakhir, namun persepsi dan prioritas aktor non-ahli (pihak awam) terkait warisan belum banyak dilibatkan dalam penilaian suatu heritage. (Heras, et al. 2019)

Selain memperluas cakupan stake holder sebagai pihak yang menginisiasi penilaian terhadap sebuah obyek heritage, diperlukan juga pemahaman mendalam terhadap pengertian nilai penting obyek heritage. Tipologi nilai penting obyek heritage sering dirancang dan diterapkan tanpa memahami konsekuensi implisit dari inklusi dan penghilangan 'nilai'. Tipologi seringkali gagal mendorong pertanyaan-pertanyaan yang diperlukan untuk mengembangkan pemahaman terperinci tentang signifikansi heritage dan menghasilkan keputusan yang didasarkan pada penilaian nilai implisit, bukan eksplisit. Kerangka studi dengan pendekatan holistik diperlukan untuk menghilangkan pemahaman dikotomi palsu tentang obyek heritage. Sehingga dapat diperoleh pemahaman yang lebih mendalam dari sekedar mengkategorisasi warisan budaya dengan kategori dikotomis warisan budaya / warisan alam, dan warisan berwujud / tidak berwujud. (Fredheim, et al. 2016).

Salah satu obyek heritage adalah peninggalan berupa bangunan industri (industrial heritage). Industrial heritage pada umumnya dilihat sebagai tonggak awal mula industrialisasi di suatu wilayah, dan biasanya dikaitkan dengan revolusi industri sebagai aspek pemengaruhnya. Jika dibandingkan dengan obyek heritage lain, prosentase industrial heritage sebagai obyek praktik heritage dunia masih sangat kecil. Daftar heritage UNESCO memperlihatkan bahwa industrial heritage belum direpresentasikan secara signifikan sepanjang abad 20 ini. Industrial heritage hanya sebesar $5,3 \%$ dari keseluruhan situs Cultural Heritage, dan hanya menempati 4\% dari seluruh situs Heritage dunia (Falser \& Yang, 2001). Di Indonesia, yang sudah masuk dalam daftar industrial heritage UNESCO baru satu yaitu bekas tambang Sawah Lunto (Asoka,dkk, 2016).

Salah satu jenis industrial heritage di Indonesia adalah pabrik gula peninggalan masa kolonial di Jawa. Sebagai bagian dari industrial heritage, pabrik gula merupakan saksi kejayaan industri gula di Jawa (Khudori. 2005). Pada kisaran tahun 1800 -an, ratusan pabrik gula yang dibangun saat itu menjadikan Jawa menjadi pemasok gula terbesar ke-dua dunia setelah Kuba (Purwadi, 2014). Pabrik gula menjadi bangunan industri dominan yang dibangun secara masif di seluruh pulau Jawa saat itu. Hal ini mengindikasikan adanya pengaruh dan peran yang begitu besar dari keberadaan pabrik gula terhadap perkembangan kota kerajaan Jawa (Wasino, 2008), dan (Padmo, 2007). Arsitektur pabrik gula menggambarkan bahwa pabrik gula dengan berbagai elemen arsitekturnya memiliki keunikan dan karakter spesifik (Inagurasi, 2010; 2013).

Perjalanan industri gula di Indonesia mencapai puncaknya tahun 1930an dengan 179 pabrik gula yang memproduksi 3 juta ton/tahun. Industri ini mengalami penurunan setelah 1930an akibat turunnya harga gula sebagai imbas dari krisis keuangan dunia (malaise). Saat itu hanya tinggal 35 pabrik gula yang bertahan dengan produksi 500.000 ton gula/tahun. Satu dekade kemudian kondisi industri gula kembali mengalami peningkatan. Di awal masa Perang Dunia II terdapat 93 pabrik gula dengan produksi 1,5 juta ton/tahun. Selama masa Perang Dunia II, industri gula kembali mengalami penurunan dengan hanya 30 pabrik gula yang berproduksi 300.000 ton/tahun. Selama tahun 1950an, produksi kembali meningkat dan menjadikan Indonesia sebagai negara eksportir gula dunia. Tahun 1957 industri gula mengalami nasionalisasi yang penuh dengan kebijakan dan regulasi. Pada tahun 1967 indonesia menjadi negara importir gula. (FAO, 1997),

Saat ini pabrik gula di Jawa menghadapi permasalahan yang kompleks. Dinamika perubahan sosial, ekonomi, politik dan lingkungan menjadi isu pokok penyebab semakin berkurangnya jumlah pabrik gula dan 
penurunan produksi gula di Jawa (Sudrajat, 2010). Dari ratusan pabrik gula yang pernah ada, tinggal 45 pabrik yang masih beroperasi. Sebagian besar dari populasi pabrik gula telah berhenti produksi dan menjadi kawasan yang tidak terawat (abandoned). Dari 45 PG BUMN aktif, rencana akan ditutup sebanyak 23 pabrik di Jawa sehingga hanya menjadi 22 pabrik pada beberapa tahun mendatang.

Pabrik gula sebagai industrial heritage berada pada kondisi rentan dan perlu perhatian khusus mengingat nilai pentingnya sebagai sumber ilmu tentang arsitektur bangunan industri dari masa lalu. Oleh karenanya, masih terbuka peluang untuk mengeksplorasi, memahami dan mengelola potensi pabrik gula sebagai industrial heritage dalam berbagai skala dan dimensinya. Wijaya, A. (2002)

\section{METODE}

Pemahaman tentang pabrik gula sebagai industrial heritage di Jawa diawali dengan kegiatan yang bersifat identifikasi. Tujuan utama dari identifikasi adalah untuk mengungkap keberadaan (populasi) seluruh pabrik gula yang pernah ada di Jawa sepanjang masa pemerintahan kolonial Hindia Belanda, kemudian memetakan sebarannya dan mengekplorasi data-data terkait dengan pabrik gula. Hasil identifikasi diharapkan dapat menjadi dasar pencarian tema-tema yang mengarah pada konsepsi nilai penting pabrik gula sebagai industrial heritage di Jawa.

Pencarian data dilakukan dengan penelusuran dari berbagai sumber secara heuristic. Penelusuran data berupa peta, daftar nama, peristiwa dan narasi sejarah yang terkait, baik dari sumber primer maupun sekunder.

Sebagai langkah awal, dibuat daftar nama pabrik gula yang pernah ada sejak jaman kolonial di seluruh wilayah Jawa sebagai dasar identifikasi. Data nama pabrik gula dihimpun dari berbagai sumber, diantaranya adalah dari arsip laporan hasil produksi gula pemerintah Hindia Belanda tahun 1886 (anonim, 1886), data dari Museum Gula dan data dari sumber sekunder lainnya. Pendataan tidak termasuk pabrik gula baru yang dibangun setelah masa kemerdekaan.
Pembahasan dilakukan dengan pendekatan sejarah secara deskriptif kualitatif. Validitas data diperoleh dengan teknik triangulasi, yaitu dengan membandingkan data dari beberapa sumber, sehingga dapat saling mengkonfirmasi.

\section{HASIL DAN PEMBAHASAN}

\subsection{Identifikasi Keberadaan Pabrik Gula}

Berdasar arsip laporan hasil produksi gula pemerintah Hindia Belanda tahun 1886 (anonim, 1886), data dari Museum Gula Gondang, hasil penelitian Inagurasi (2010) dan beberapa sumber lain, paling tidak terdapat 231 pabrik gula sebagai industrial heritage di Jawa. Pabrik gula yang di identifikasi meliputi semua pabrik gula yang dibangun pada masa pemerintahan kolonial Belanda antara tahun 1800-an sampai dengan tahun 1900-an. Jumlah ini tidak termasuk beberapa pabrik gula kecil milik orang Tionghoa di sekitar Batavia yang masih berupa industri rumahan skala kecil dengan tenaga manual, dan juga pabrik baru yang dibangun setelah masa kemerdekaan. Nama pabrik gula dan peta sebaran pabrik gula peninggalan masa kolonial di Jawa dapat dilihat pada Lampiran 1.

Jika dilihat dari namanya, nama pabrik gula cenderung menggunakan nama tempat di mana pabrik itu berada. Jika dilihat dari sebarannya, sebagian besar pabrik gula ada di wilayah Jawa Timur dengan 120 pabrik, kemudian di Jawa Tengah dengan 66 pabrik, Jawa Barat dengan 25 pabrik dan Yogyakarta dengan 20 pabrik.

Prosentase jumlah pabrik gula di Jawa Timur sebesar 51,9 \%, Jawa Tengah sebesar 28,5\%, Jawa Barat sebesar 10,8 \% dan Yogyakarta sebesar 8,6\%.

Info sebaran seluruh pabrik gula yang pernah ada di Jawa di masing-masing wilayah dapat dilihat pada Gambar 1 


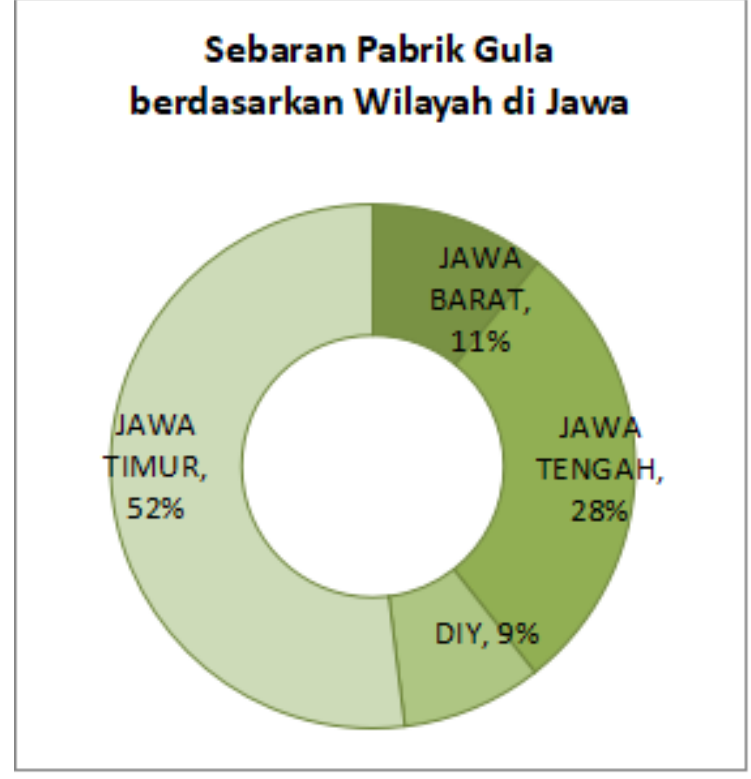

Gambar 1. Sebaran Pabrik Gula yang Pernah Ada di Jawa berdasarkan Wilayah

\subsection{Kondisi Fisik Pabrik Gula}

Kondisi fisik pabrik gula peninggalan masa kolonial di Jawa pada saat ini dapat dikategorikan dalam empat kondisi yaitu:

1) Bangunan pabrik secara fisik sudah tidak ada, sekalipun masih dapat ditemukan jejak fisik lebih berupa puing atau lokasi tempat dengan nama spesifik. Bukti keberadaanya hanya dapat dilihat dari nama lokasi dan informasi sejarah berupa cerita, tulisan atau foto. Secara umum area pabrik gula sudah berubah fungsinya menjadi permukiman, kantor, fasilitas pendidikan dan lain-lain.

2) Bangunan pabrik masih terlihat jelas dan batas lokasi kompleks pabrik masih terjaga. Pabrik gula dalam kategori ini sudah tidak berfungsi dan cenderung tidak terawat (mangkrak). Sebagian ada yang dalam kondisi masih baik, namun secara umum kondisinya rusak parah.

3) Pabrik gula dengan kondisi fisik masih baik dan cukup terawat. Pabrik gula dalam kategori ini dapat dibedakan menjadi dua sub kategori yaitu pabrik gula yang masih beroperasi sesuai dengan fungsinya, dan pabrik gula yang sudah beralih fungsi, dengan merubah dan menambahkan sebagian fisik bangunannya.

Prosentase kondisi fisik pabrik gula peninggalan masa kolonial dapat dilihat pada Gambar 2.

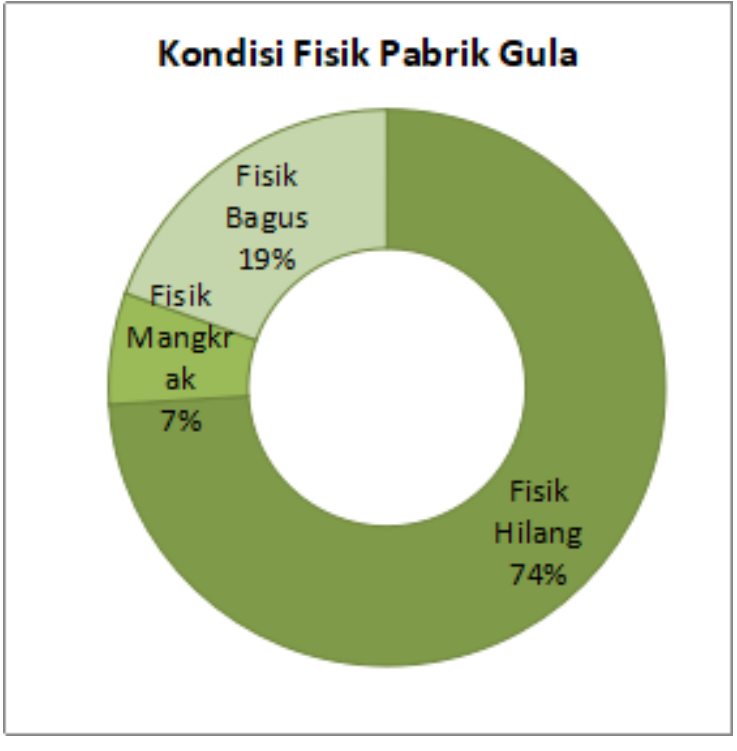

Gambar 2. Kondisi Fisik Pabrik Gula yang Pernah ada di Jawa

\subsection{Usia pabrik gula di Jawa}

Jika dilihat dari usianya, pabrik gula peninggalan masa kolonial di Jawa dapat dikelompokkan dalam tiga kategori yaitu: Pabrik gula berusia 50 sampai dengan 100 tahun, pabrik gula dengan usia 100 sampai 150 tahun dan pabrik gula yang usianya di atas 150 tahun.

Hampir semua pabrik gula pada masingmasing wilayah didominasi pabrik dengan umur lebih dari 150 tahun (kecuali di Yogyakarta yang usia pabriknya di bawah 150 tahun). Mayoritas bangunan pabrik gula di Jawa sudah berusia lebih dari 100 tahun, sehingga jika hanya dilihat dari aspek usia, maka semua pabrik gula peninggalan masa kolonial telah memenuhi syarat sebagai bangunan cagar budaya, yang mensyaratkan usia minimal 50 tahun.

Sebaran seluruh pabrik gula yang pernah ada di Jawa di masing-masing wilayah berdasar usianya dapat dilihat pada Gambar 3 
Purwanto Setyo N, Nany Yuliastuti, R Siti Rukayah, Rachmadi Nugroho, Untung J.C, Identifikasi Pabrik...

\section{Sebaran Pabrik Gula yang Pernah Ada di Jawa dan usianya}

50 sd 100 tahun $\quad 100$ sd 150 tahun

diatas 150 tahun

65
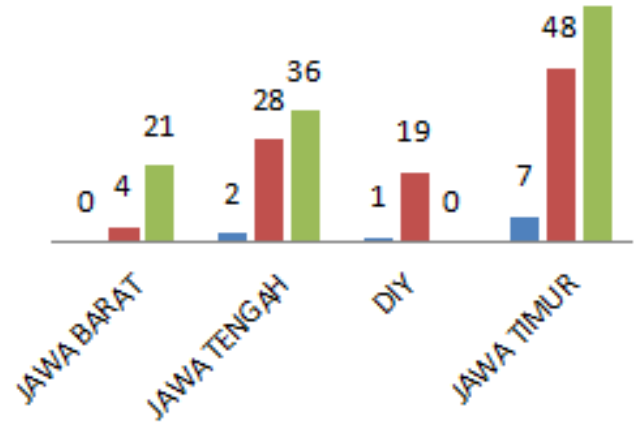

Gambar 3. Sebaran Pabrik Gula yang Pernah Ada di Jawa dan usianya

\subsection{Pabrik Gula yang Masih Aktif}

Sampai tahun 2019, jumlah pabrik gula peninggalan masa kolonial di pulau Jawa yang masih aktif beroperasi sesuai fungsi sebanyak 45 pabrik. (Lihat Tabel 1).

Tabel 1. Daftar Pabrik Gula Peninggalan Masa Kolonial yang masih Aktif di Jawa

\begin{tabular}{|l|l|l|l|}
\hline \multirow{2}{*}{ No } & \multirow{2}{*}{$\begin{array}{c}\text { Nama Pabrik Gula } \\
\text { (PG) / }\end{array}$} & \multicolumn{2}{|c|}{$\begin{array}{c}\text { Lokasi / } \\
\text { Afdeeling }\end{array}$} \\
\cline { 3 - 4 } & Ondernemingen & \multicolumn{1}{|c|}{ Propinsi } & \multicolumn{1}{|c|}{ Kabupaten } \\
\hline 1 & PG Tersana Baru & Jawa Barat & Cirebon \\
\hline 2 & PG Sindanglaut & Jawa Barat & Cirebon \\
\hline 3 & PG Jatibarang & Jawa Tengah & Brebes \\
\hline 4 & PG Tasikmadu & Jawa Tengah & Karanganyar \\
\hline 5 & PG Cepiring & Jawa Tengah & Kendal \\
\hline 6 & $\begin{array}{l}\text { PG Gondang } \\
\text { Winangun }\end{array}$ & Jawa Tengah & Klaten \\
\hline 7 & PG Rendeng & Jawa Tengah & Kudus \\
\hline 8 & PG Trangkil & Jawa Tengah & Pati \\
\hline 9 & PG Pakis Baru & Jawa Tengah & Pati \\
\hline 10 & PG Pangkah & Jawa Tengah & Pekalongan \\
\hline 11 & PG Sragi & Jawa Tengah & Pekalongan \\
\hline 12 & PG Sumberharjo & Jawa Tengah & Pemalang \\
\hline 13 & PG Mojo & Jawa Tengah & Sragen \\
\hline 14 & $\begin{array}{l}\text { PG } \\
\text { Prajekan/Lumutan }\end{array}$ & Jawa Timur & Bondowoso \\
\hline 15 & PG Semboro & Jawa Timur & Jember \\
\hline 16 & PG Jombang & Jawa Timur & Jombang \\
\hline 17 & PG Cukir & Jawa Timur & Jombang \\
\hline 18 & PG Pesantren & Jawa Timur & Kediri \\
\hline
\end{tabular}

\begin{tabular}{|l|l|l|l|}
\hline \multirow{2}{*}{ No } & \multirow{2}{*}{$\begin{array}{c}\text { Nama Pabrik Gula } \\
\text { (PG) / }\end{array}$} & $\begin{array}{c}|c| \\
\text { Ondernemingen }\end{array}$ & \multicolumn{1}{|c|}{ Pokasi / } \\
\cline { 3 - 4 } 19 & PG Merican & Jawa Timur & Kabupaten \\
\hline 20 & PG Ngadirejo & Jawa Timur & Kediri \\
\hline 21 & PG Jatiroto & Jawa Timur & Lumajang \\
\hline 22 & PG Kanigoro & Jawa Timur & Madiun \\
\hline 23 & PG Pagotan & Jawa Timur & Madiun \\
\hline 24 & PG Rejoagung & Jawa Timur & Madiun \\
\hline 25 & PG Purwodadi & Jawa Timur & Magetan \\
\hline 26 & PG Rejosari & Jawa Timur & Magetan \\
\hline 27 & PG Kebonagung & Jawa Timur & Malang \\
\hline 28 & PG Krebet Baru & Jawa Timur & Malang \\
\hline 29 & PG Gempolkerep & Jawa Timur & Mojokerto \\
\hline 30 & PG Lestari & Jawa Timur & Nganjuk \\
\hline 31 & PG Sudono & Jawa Timur & Ngawi \\
\hline 32 & PG Kedawung & Jawa Timur & Pasuruan \\
\hline 33 & PG Pajarakan & Jawa Timur & Probolinggo \\
\hline 34 & PG Wonolangan & Jawa Timur & Probolinggo \\
\hline 35 & PG Gending & Jawa Timur & Probolinggo \\
\hline 36 & PG Candi & Jawa Timur & Sidoarjo \\
\hline 37 & PG Krembung & Jawa Timur & Sidoarjo \\
\hline 38 & PG Olean & Jawa Timur & Situbondo \\
\hline 39 & PG Wringinanom & Jawa Timur & Situbondo \\
\hline 40 & PG Panji & Jawa Timur & Situbondo \\
\hline 41 & PG Asembagus & Jawa Timur & Situbondo \\
\hline 42 & $\begin{array}{l}\text { PG } \\
\text { Mojopanggong }\end{array}$ & Jawa Timur & Tulungagung \\
\hline 43 & PG Watutulis & Jawa Timur & Sidoarjo \\
\hline 44 & PG Tulangan & Jawa Timur & Sidoarjo \\
\hline 45 & PG Madukismo & Yogyakarta & Bantul \\
\hline
\end{tabular}

Sebaran pabrik gula yang masih aktif dan yang tidak aktif di Pulau Jawa dapat di lihat lebih detail pada Gambar 4.

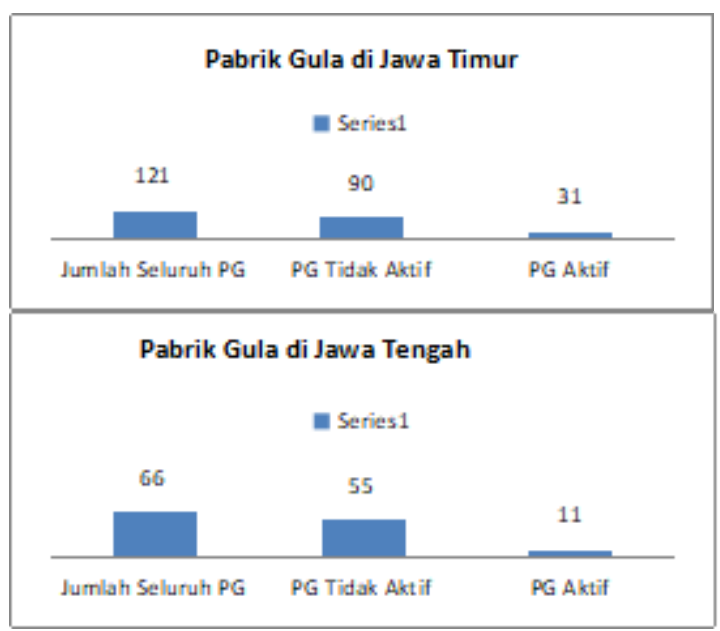




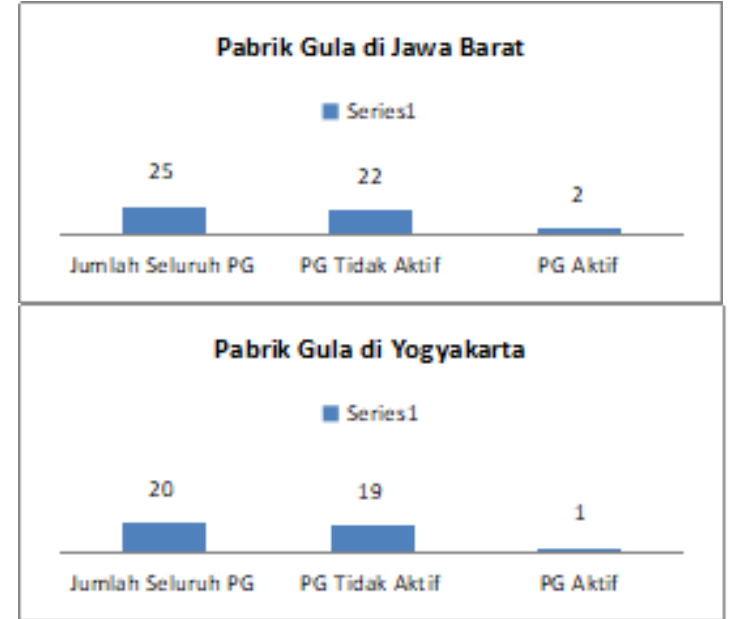

Gambar 4. Sebaran Pabrik Gula yang Aktif dan Tidak aktif di Jawa.

Prosentase pabrik gula aktif dari jumlah seluruh pabrik gula pada masing masing wilayah di Jawa, dari urutan terbesar adalah: Jawa Timur sebesar 25\% (31 PG aktif dari total $121 \mathrm{PG})$, kemudian Jawa Tengah sebesar $16 \%$ (11 PG aktif dari total 66 PG), Jawa Barat sebesar $9 \%$ ( 2 PG aktif dari total 22 PG) dan Yogyakarta sebesar 5\% (1 PG aktif dari total 20 PG).

Ada rencana penutupan dari 45 pabrik gula BUMN aktif. Selama beberapa tahun ke depan rencana akan ditutup sebanyak 23 pabrik di Jawa sehingga hanya menjadi 22 pabrik.

Sebaran pabrik gula aktif di Jawa berdasar usia dapat dilihat pada Gambar 5.

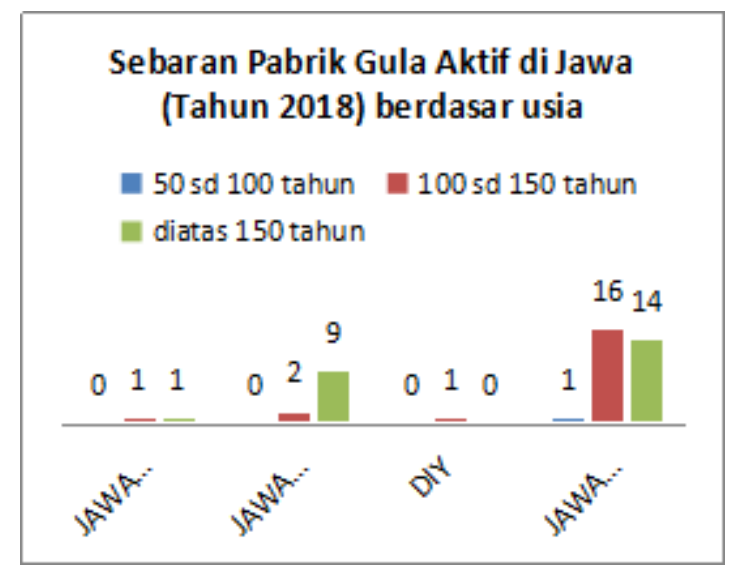

Gambar 5. Sebaran Pabrik Gula yang Masih Aktif di Jawa berdasar usia (sampai tahun 2019)

\subsection{Kepemilikan Awal Pabrik Gula}

Berdasarkan pemilik pada saat awal pendiriannya, pabrik gula peninggalan masa kolonial di Jawa dapat dikategorikan menjadi tiga yaitu: pabrik gula milik Pemerintah kolonial/Swasta Belanda, Pabrik gula milik Pengusaha Cina, dan pabrik gula milik Raja Jawa. Awal kepemilikan pabrik gula didominasi oleh kepemilikan perorangan Belanda. Setelah masa krisis ekonomi melanda dunia, kepemilikan pabrik gula berubah dari perseorangan menjadi kepemilikan korporasi. Korporasi ini merupakan gabungan beberapa pengusaha dan lembaga keuangan yang mengambil alih dari pihak perseorangan (Wiseman, 2001). Prosentase masing masing dapat dilihat pada Gambar 6

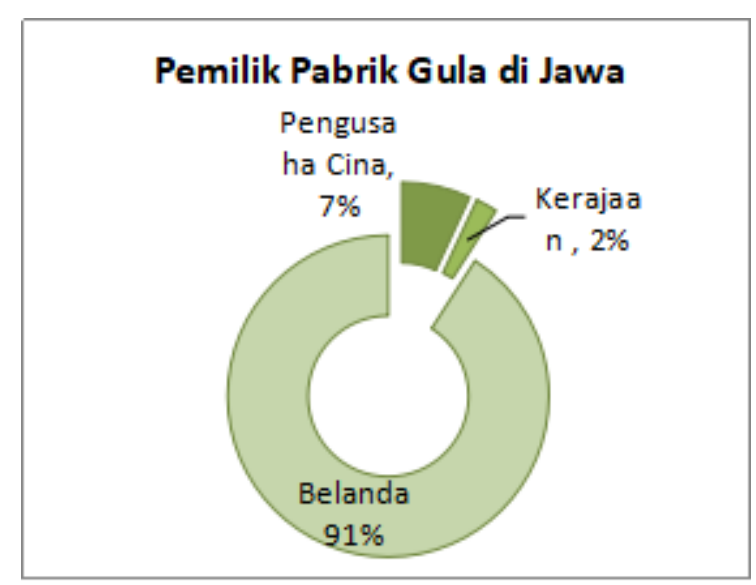

Gambar 6. Prosentase pabrik gula berdasar kepemilikan Awal

\subsection{Langgam Arsitektur Pabrik Gula}

Penelusuran langgam arsitektur bangunan pabrik gula tidak lepas dari sejarah perkembangan arsitektur kolonial di Indonesia. Kehadiran bangsa Eropa di Indonesia memperkenalkan gaya seni arsitektur modern saat itu. Pada abad ke-19-awal abad ke-20 muncul pengaruh gaya $\mathrm{Art} \& \mathrm{Craft}$, yaitu gaya desain sebagai reaksi terhadap revolusi industri yang sangat menghargai seni \& kerajinan. Karakternya adalah penggunaan unsur garis lengkung dengan inspirasi dari alam. Gaya ini kemudian berkembang menjadi dua Art Deco dan Art Nouveau . 
Langgam arsitektur pabrik gula terlihat pada bangunan utama pabrik (emplasemen) dan pada bangunan penunjangnya, terutama bangunan dengan fungsi hunian. Threesje, dkk. (2012). Jika dilihat dari langgamnya, arsitektur pabrik gula cenderung dipengaruhi aliran yang baru berkembang saat itu yaitu gaya Art Deco. Tampilan beberapa bangunan utama pabrik gula dapat di lihat di Gambar 7.

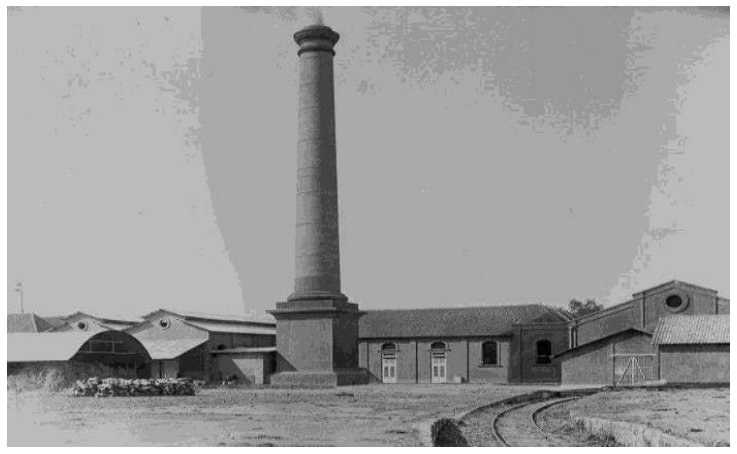

PG Karangsuwung, Jawa Barat. (Sumber: Tropical Museum)

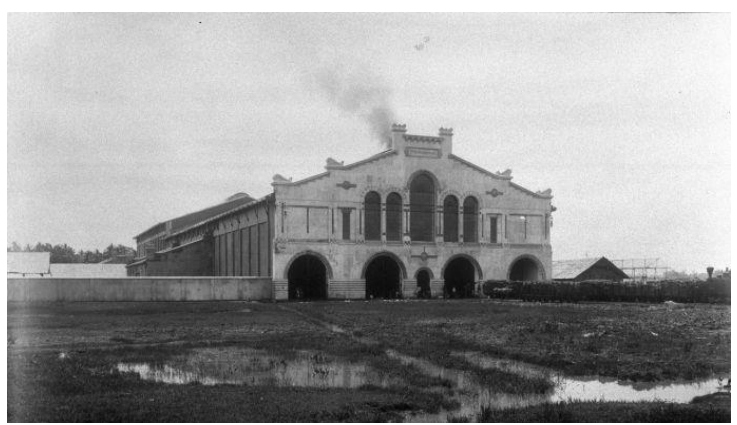

PG Poerworedjo, November 1910. Jawa Tengah. (Sumber: Tropical Museum)

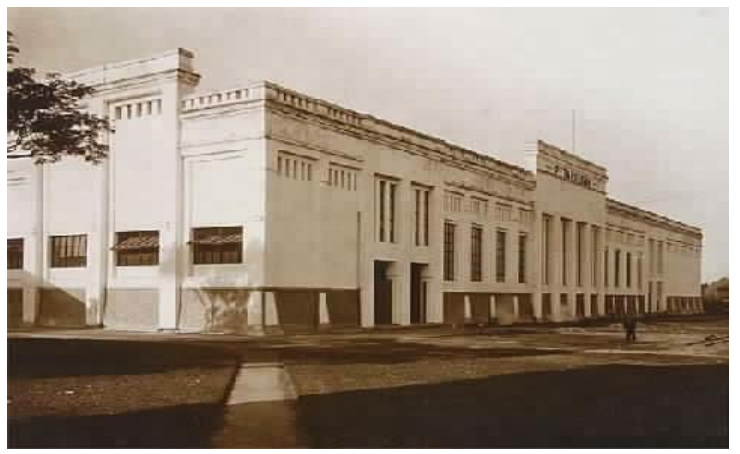

PG Petarukan, Pemalang, Jawa Tengah. (Sumber: Tropical Museum)

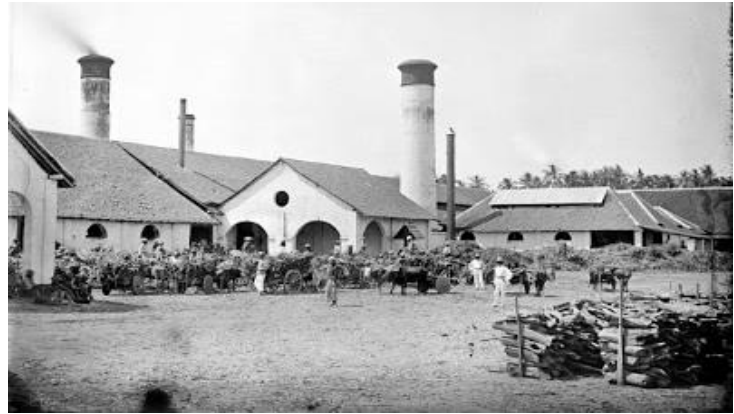

PG Kandang Jati, Pasoeroean, Jawa Timur, Tahun 1900. (Sumber: Tropical Museum)

Gambar 7. Tampilan bangunan utama pabrik gula Sumber: Tropical Museum

\subsection{Aspek Kesejarahan Pabrik Gula}

Aspek kesejarahan pabrik gula menyangkut peristiwa atau kejadian penting yang mencakup dimensi cukup luas dan bersifat relatif. Untuk itu, disiplin ilmu arsitektur perlu dilihat dari perspektif sejarah kesenian yang melihat bahwa data arsitektural dapat mewakili sebuah perkembangan pemikiran; orientasi seni dan tehnologi. Selain itu dapat dipertimbangkan juga kejadian bersejarah yang dianggap memiliki nilai penting dalam perjalanan sejarah kehidupan bangsa yang melibatkan pabrik gula.

Sejarah penting pabrik gula kemudian dapat dinilai dari aspek inovasi dan momen penting yang melibatkannya. Sebagai contoh, perkembangan pemikiran terkait pabrik gula dapat dilihat dari inovasi dari Raja Mangkunegaran dalam menjalankan usaha industri gula, sehingga tercatat sebagai salah satu kapitalis bumi putra (Wasino, 2008), yang telah menerapkan pemerintahan kerajaan secara modern (Wasino, 2012). Inovasi teknologi pabrik gula dapat dilihat dari penggunaan mesin-mesin pengolahan tebunya, yang secara umum dapat dibagi menjadi tiga kategori yatu, mesin dengan tenaga penggerak manual (hewan/manusia), mesin dengan tenaga uap air, dan mesin bertenaga listrik. Nilai kesejarahan pabrik gula juga dapat dilihat dari peristiwa penting yang melibatkan pabrik gula dalam memberi kontribusi sejarah perjuangan bangsa dalam meraih kemerdekaan. 


\subsection{Nilai Penting Pabrik Gula.}

Hasil identifikasi pabrik gula peninggalan masa kolonial di Jawa dapat dikategorisasikan dari aspek lokasi, usia, fungsi, kepemilikan awal, kondisi fisik, langgam arsitektur dan aspek peristiwa bersejarah yang terkait dengannya. Penetapan sebuah pabrik gula sebagai sebuah cagar budaya kemudian dapat ditentukan berdasar seberapa besar nilai pentingnya. Berdasarkan aspek lokasi, umur, fungsi, kepemilikan awal, kondisi fisik, langgam arsitektur dan peristiwa sejarah yang melibatkannya, penetapan nilai penting sebuah pabrik gula sebagai cagar budaya kemudian dapat ditentukan berdasar pada aspek kelangkaan/keunikan.

Jika dilihat dari lokasi, kelangkaan pabrik gula dapat dinilai dari sebarannya di empat wilayah yaitu: Jawa Barat, Jawa Tengah, Daerah Istimewa Yogyakarta dan Jawa Timur. Populasi yang sedikit perlu dilihat sebagai prioritas dalam menilai kelangkaan.

Jika dilihat dari usia, kelangkaan pabrik gula dapat dinilai dari kategori usianya yang dapat dibagi dalam kelompok usia di atas 150 tahun, antara 100 sampai dengan 150 tahun dan di bawah 100 tahun. Jika merujuk pada peraturan tentang Benda Cagar Budaya yang minimal harus berusia 50 tahun, maka seluruh pabrik gula peninggalan masa kolonial memenuhi syarat sebagai Benda Cagar Budaya. Namun demikian pertimbangan dari aspek lain perlu dikaitkan.

Jika dilihat dari fungsi/kegiatannya, kelangkaan pabrik gula dapat dinilai dari keberlangsungan fungsinya, apakah masih beroperasi dengan baik, sudah berhenti atau berubah menjadi fungsi lain. Pabrik yang masih berfungsi dengan baik dan terawat perlu mendapat perhatian untuk pelestariannya, karena memiliki peran bagi kehidupan masyarakat sekitarnya. Nurrati; dkk. (2013).

Jika dilihat dari kepemilikan pada saat awal pendiriannya, kelangkaan pabrik gula dapat dinilai dari pemiliknya, apakah milik pemerintah kolonial/swasta Belanda, pengusaha Cina, atau pabrik milik raja Jawa.

Jika dilihat dari kondisi fisik, nilai penting pabrik gula dapat dinilai dari keberadaan dan kondisi fisik bangunannya, apakah sudah tidak ada (hanya sisa-sisa), atau jika masih ada apakah kondisinya rusak parah, atau masih utuh dan aktif sesuai fungsinya.

Jika dilihat dari langgam arsitekturnya, nilai penting pabrik gula dapat dinilai dari kejelasan langgam dan kualitas detailnya. Sehingga pabrik gula dapat dikategorikan menjadi dua yaitu: langgam jelas terdeteksi dan langgam tidak terdeteksi/samar.

Jika dilihat dari kesejarahannya, nilai penting pabrik gula dapat ditentukan dengan melihat bagaimana peran/keterlibatan sebuah pabrik gula dalam peristiwa penting bersejarah terkait dengan kehidupan masyarakat, bangsa dan negara. Sehingga pabrik gula dapat dikelompokkan menjadi dua yaitu pabrik gula yang menjadi seting peristiwa bersejarah dan pabrik gula yang tidak tercatat mengalami peristiwa bersejarah.

Kategori pabrik gula terkait nilai pentingnya dapat diihat pada tabel 2 sebagai berikut:

Tabel 2. Kategori Pabrik Gula Terkait dengan Nilai Penting

\begin{tabular}{|c|c|c|c|c|}
\hline No & Aspek & \multicolumn{3}{|c|}{ Kategori Pabrik Gula } \\
\hline 1 & Lokasi & $\begin{array}{c}\text { Jawa } \\
\text { Barat }\end{array}$ & $\begin{array}{c}\text { Jawa Tengah/ } \\
\text { DIY }\end{array}$ & $\begin{array}{c}\text { Jawa } \\
\text { Timur }\end{array}$ \\
\hline 2 & Usia & $>100$ & 50 sd 100 & $<50$ \\
\hline 3 & Fungsi & $\begin{array}{c}\text { Beroper } \\
\text { asi }\end{array}$ & $\begin{array}{c}\text { Berhenti } \\
\text { beroperasi }\end{array}$ & $\begin{array}{c}\text { Berub } \\
\text { ah } \\
\text { fungsi }\end{array}$ \\
\hline 4 & $\begin{array}{c}\text { PemilikA } \\
\text { wal }\end{array}$ & Belanda & Swasta Cina & $\begin{array}{c}\text { Raja } \\
\text { Jawa }\end{array}$ \\
\hline 5 & $\begin{array}{c}\text { Kondisi } \\
\text { fisik }\end{array}$ & $\begin{array}{c}\text { Utuh } \\
\text { terawat }\end{array}$ & $\begin{array}{c}\text { Rusak, tak } \\
\text { terawat }\end{array}$ & $\begin{array}{c}\text { puing/ } \\
\text { hilang }\end{array}$ \\
\hline 6 & $\begin{array}{c}\text { style } \\
\text { Arsitektur }\end{array}$ & $\begin{array}{c}\text { terdetek } \\
\text { si }\end{array}$ & \multicolumn{2}{|c|}{$\begin{array}{c}\text { Samar/ } \\
\text { Tidak terdeteksi }\end{array}$} \\
\hline 7 & Sejarah & penting & \multicolumn{3}{|c|}{ Tidak penting } \\
\hline
\end{tabular}

\section{KESIMPULAN}

Hasil identifikasi terhadap keberadaan pabrik gula peninggalan masa kolonial Belanda di pulau Jawa menunjukkan paling tidak terdapat 231 pabrik gula yang dibangun sejak awal tahun 1800-an sampai saat ini. Sebaran pabrik gula terkonsentrasi di sebagian besar wilayah Jawa Tengah, Daerah Istimewa Yogyakarta dan Jawa Timur.

Nilai penting pabrik gula sebagai industrial heritage dapat ditetapkan berdasar aspek lokasi, usia, fungsi, kepemilikan awal, kondisi fisik, langgam arsitektur dan aspek peristiwa bersejarah yang terkait dengannya. 
Kegiatan identifikasi ini merupakan penelitian awal tentang pabrik gula, dan perlu di lanjutkan dengan penelitian lanjutan yang lebih mendalam terkait substansi nilai penting pabrik gula sebagai industrial heritage di Jawa, khususnya dalam disiplin bidang arsitektur.

\section{UCAPAN TERIMAKASIH}

Terimakasih kepada kami ucapkan kepada Program Doktor Ilmu Arsitektur dan Perkotaan Universitas Diponegoro Semarang yang telah memberikan dukungan sarana dan prasarana dalam kegiatan penelitian.

\section{REFERENSI}

Asoka; dkk. (2016). Sawah Lunto Dulu, Kini, dan Esok (Menjadi Kota Wisata Tambang yang Berbudaya). Sawah Lunto: Lembaga Pengembangan Teknologi Informasi dan Komunikasi (LPTIK).

Falser, M., \& Yang, M. (2001). Industrial Heritage Analysis. World Heritage List and Tentative List, Global Strategy Studies, UNESCO, World Heritage Centre, Asia-Pacific Region (hal 13). Retrieved from http://whc.unesco.org/archive/indstudy01.pdf

FAO (1997), Theoretical Outlook, Framework Analysys and Background Documentation, Proceedings, Fiji/Fao Asia Pacific Sugar Conference. Retrieved from http://www.fao.org/docrep/005/X0513E/x05 $13 \mathrm{e} 21 . \mathrm{htm}$

Fredheim L, et al, (2016). The significance of values: heritage value typologies reexamined, International Journal of Heritage Studies (2016) 22(6) 466-481. DOI: $\underline{10.1080 / 13527258.2016 .1171247}$

Groat;Wang. (2002). Architectural Research Methods. Canada: John Wiley and Sons.Inc.

Heras V, et al, (2019) Heritage values: towards a holistic and participatory management approach, Journal of Cultural Heritage Management and Sustainable Development (2019) 9(2) 199-211. DOI: $10.1108 / \mathrm{JCHMSD}-10-2017-0070$

Inagurasi, Libra Hari. 2010. Pabrik Gula Cepiring di Kendal, Jawa Tengah, Tahun 1835-1930, Sebuah Studi Arkeologi Industri. Tesis, Program Studi Magister Arkeologi,Fakultas Ilmu Pengetahuan Budaya, Universitas Indonesia
Inagurasi, Libra Hari (2013) Aspek Penelitian dalam Pengelolaan Pabrik Gula. Laporan Penelitian, Puslitbang Arkenas.

Khudori. (2005). Gula Rasa Neoliberalisme: Pergumulan Empat Abad Industri Gula. Jakarta: Pustaka LP3ES.

Lagerqvist, B. (2011). Industrial heritage and heritage practices, Paper, Departemen of Conservation, Universityof Gothenburg114.

Logunov, E. (2003). The Nizhny Tagil Charter for the Industrial Heritage. The International Committee for the Conservation of the Industrial Heritage (TICCIH), 1-6. https://doi.org/10.1002/path.1845

Nurrati; dkk. (2013). Eksistensi Pabrik Gula Poerwodadie dan Pengaruhnya Terhadap Perubahan Sosial Ekonomi Masyarakat Desa Pelem, Kecamatan Karangrejo, Kabupaten Magetan. Laporan penelitian Universitas Sebelas Maret. Retrieved from http://www.ncbi.nlm.nih.gov/entrez/query.fc gi?cmd=Retrieve $\& \mathrm{db}=$ PubMed \&dopt=Citati on\&list uids $=15073293$

Padmo, S. (2007). Sejarah Kota Dan Ekonomi Perkebunan, Makalah dalam Diskusi Sejarah.oleh Balai Pelestarian Sejarah dan Nilai Tradisional Departemen Kebudayaan dan Pariwisata, Yogyakarta

Purwadi (2014), Gula dalam Kajian Filsafat Budaya Jawa, Jurnal Ikadbudi Vol.3, Oktober 2014, ISSN:2089-7537

Sudrajat, Hasan (2010) Model of Sustainable Sugar Industry Development Based on Clean Development Mechanism and Society Participation, Laporan Penelitian IPB.

Threesje A. Harimu, Antariksa, \& Dwi Wulandari, L. (2012). Tipologi Wajah Bangunan Arsitektur Kolonial Belanda Di Kawasan Pabrik Gula Semboro-Jember. ARSKON, Jurnal Arsitektur \& Konstruksi, 1(1), 66-79.

Wasino. (2008). Kapitalisme Bumi Putra: Perubahan Masyarakat Mangkunegaran. Yogyakarta: LKiS.

Wasino, (2012) Modernisasi Pemerintahan Praja Mangkunagaran Surakarta, Jurnal Paramita Vol. 22 No. 1-Januari 2012 [ISSN: 08540039] hal 25-40

Wijaya, A. (2002). Laporan Penelitian "Eksplorasi Tema Perancangan pada Pabrik Gula Tasikmadoe”, Jurusan Arsitektur, Fakultas Teknik, Universitas Katolik Soegijapranata, Semarang

Wiseman, R. (2001). Three Crises: Management in The Colonial Java Sugar Industry 1880s1930s. Thesis on Doctor of Philosopy,University of Adelaide, Departement of History. 
Lampiran 1

SEBARAN PABRIK GULA PENINGGALAN KOLONIAL DI PULAU JAWA

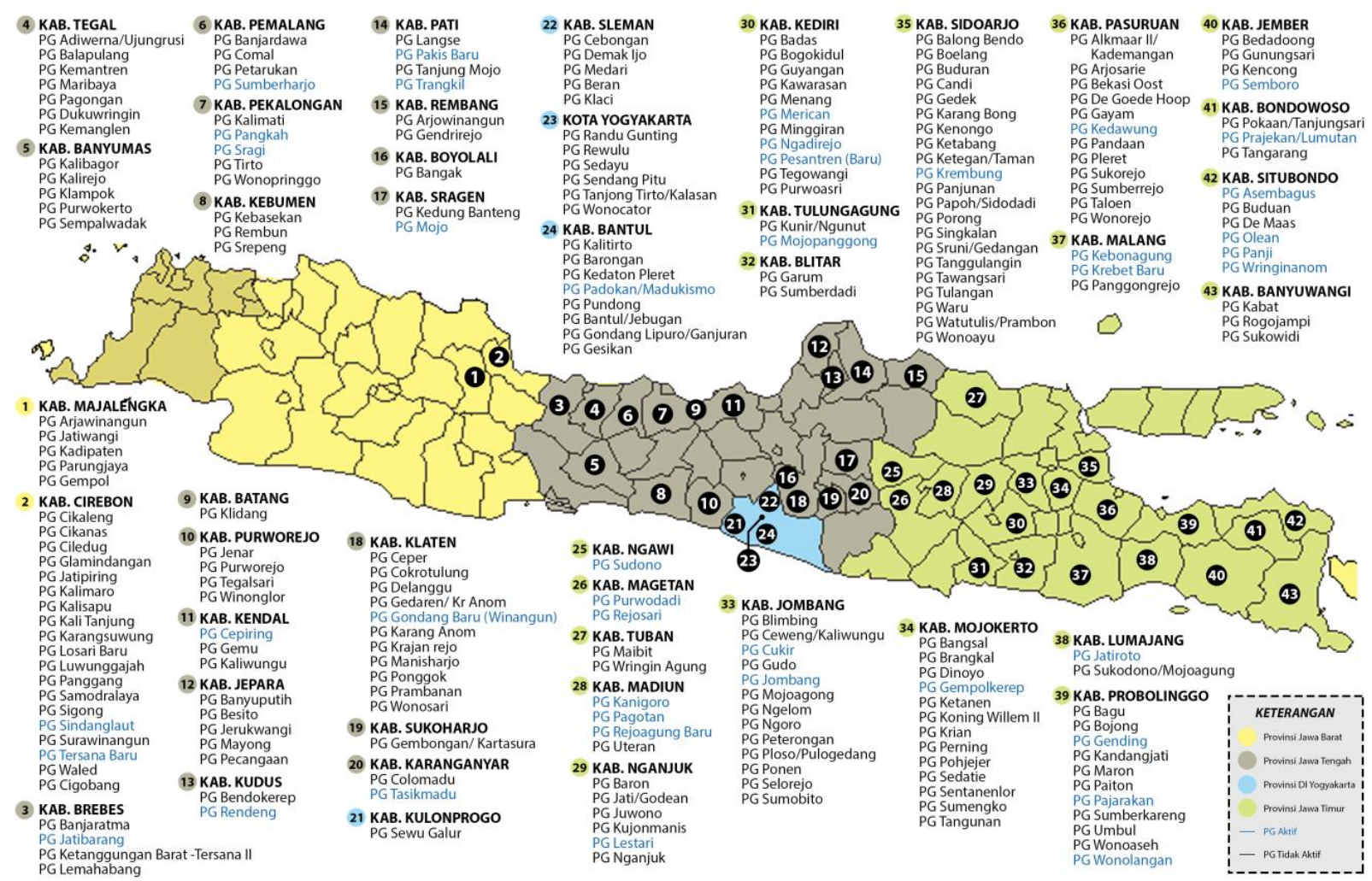

Sumber: Penulis, diolah dari berbagai sumber (2019) 